\title{
AN ENGLISH ACTION RESEARCH FOR A BETTER LIFE (EBL)
}

\section{Tarmizi Rasul; Imam Suseno}

\author{
Program of English Education, Faculty of Language and Art, University of Indraprasta PGRI \\ Jalan Nangka No. 58C Tanjung Barat, Jagakarsa, South Jakarta 12530 \\ tarmiziguchi@gmail.com and susenoblr@gmail.com
}

\begin{abstract}
English is a foreign language in this country which is needed by all sides especially by teenagers since English, both competence and performance, will be always needed by workers in all kinds of jobs. The teenagers in kelurahan Cipedak Jagakarsa South Jakarta have been united in a teenagers organization which is called Karang Taruna. They were enthusiastic to engage in an English Action Research called EBL (English for A Better Life). EBL was an activity as an English action being carried out by implementing an Oral Questioning Guidance in L1 (OQIGIL) method. This OQIGIL method aimed at improving the awareness of teaching of a teacher to increase his students' communication skills. An OQIGIL method developed from time to time was based on a systematic procedure and focused on a certain quality or a standard, an accurateness and a certain efficiency as well. After this EBL was undertaken several times, the students' competence and performance improved better.
\end{abstract}

Keywords : an English action research, EBL, OQIGIL

\section{ABSTRAK}

Bahasa Inggris adalah bahasa asing yang sangat dibutuhkan oleh semua pihak khususnya generasi muda. Sebab kemampuan bahasa Inggris baik sebagai ilmu pengetahuan ataupun suatu keterampilan akan selalu dibutuhkan dalam dunia kerja. Remaja kelurahan Cipedak Jagakarsa Jakarta Selatan yang sudah terhimpun dalam wadah Karang Taruna sebagai pembelajar sangat antusias mengikuti dan terlibat dalam kegiatan tindakan bahasa Inggris yang disebut sebagai EBL (English for A Better Life). Kegiatan EBL sebagai tindakan bahasa Inggris secara operasional melaksanakan penerapan metode Oral Questioning Guidance in L1 (OQIGIL) agar pengajar bahasa Inggris selalu menginstrospeksi diri untuk meningkatkan kualitas mengajarnya sehingga peserta didiknya mampu berbicara dalam bahasa Inggris setelah mengikuti kegiatan ini. Model pembelajaran Oral Questioning in L1 (OQIL) berkembang berdasarkan prosedur secara sistematis berdasarkan pada kualitas, atau standar, ketepatan dan keefisienan tertentu. Sesudah English For A better Life tahap ini berjalan pada beberapa kali pertemuan, sikap dan kemampuan berbahasa Inggris pembelajar mengalami peningkatan.

Kata Kunci: penelitian tindakan Bahasa Inggris, EBL, OQIGIL

\section{INTRODUCTION}

The teenagers in RT 001/RW 02 kelurahan Cipedak Jagakarsa South Jakarta having been united in Karang
Taruna Organization that had studied English in the first level of EBL program taken more or less three months were not able to communicate 
in English. It was because some of them such as the leader of Karang Taruna was very busy in his campus and the other participants were too. The other case was that there were five participants in one group which could not attend the class since their leader was absent and so were her members. It happened to her, since she was grade 12 in of one private vocational high schools and she had an overlapping schedule as well. In fact, this group members attended EBL program temporarily. They looked unconfident since the English grammar was complicated to learn. At last, they were asshamed of attending this EBL program.

It was one of the issues which was disscussed by the head of RT 01 RW 02 kelurahan Cipedak Jagakarsa South Jakarta. Then, he suggested that the teenagers be boosted to learn on a second EBL program since there was no an activity to activate the teenagers to get a special skill. If not, they would waste the time; consequently, they could abuse the drug.

The head of RT 01 RW 02 added that some of the teenagers were seldom active to cooperate in a positive activity. In general, they were in their house and went to school as usual. There was no friend in their enviroment except they went to their classmate's house in different area. In fact, some of the other ones usually chatted in the corner of the house to waste their time without getting anything. According to the head of RT 01 RW 02 that Karang Taruna is an organization of teenagers to unite them. There was an EBL program which was needed by them to prepare their future. The head of RT 01 highly appreciated this EBL program. Therefore, one of his daughters joined this EBL program enthusiastically.
Furthermore, English is an international language which is needed by the teenagers such as (1) to improve their English scores in their report cards, (2) to prepare their national passing grades since English is one of the subjects which is examined, (3) to prepare them to entrance exam of university, (4) to get a better job both in domestic and overseas, (5) to be promoted in all level of jobs both state and private company, (6) for TOEFL preparation when they apply for a job anytime.

In addition, an adolescene started 12-15 years which is regarded as an unstable age (Sriyono, 2011). There are many problems coming up in their minds occasionally. Yusuf in Sriyono (2011) stated that the teenagers grew a motivation in their souls to survive and they need friends to overcome their problems. There are many kinds of problems that are being faced by teenagers when they are an adolescene namely, how to handle their desire while they have many things to do in their everyday life. Consequently, they are stressful. Yusuf in Sangabakti (2011) said that stress is a bad mood as a responce of individual on stressor that against or endanger, desire, safety, interest or welfare of their life.

There are many strategies which can be done to help the teenagers who are in trouble in English. One of them is a study guidance. According to Shertzer and Stone in Sriyono (2011:112) that a study guidance is "A prosess of helping an individual to understand himself and his world". Such guidances come up as solutions. One of them is a peer group. It can be the same age, their senior or a teacher. A teacher in this case should accommodate a good teaching strategy which can create active learning situation in many different learning 
style (James in Supriyanto, 2006). Yet, it is a trusted person who can help to overcome the problem. Sukardi in Sangabakti (2011:139) said that "Counseling was meant to enable the students to get the best solution from all sides especially from their councelor teacher". It is not only as an individual, a student, a family member and also a citizen of society.

It is a need for learners to expose themselves to the target language as they will be imposed to be native like in interaction with mates (Blake, 2009). Therefore, the students are asked for closer and closer to inform or to express their problems to their friends. After they have expressed their issues to their friends, they are expected to be not stressfull anymore. Their advisor has an important role to facilitate it accurately, honestly, and intelligently and full of affection. Gladding in Sangabakti (2011:139) said that "The role of group leader was needed to consider the detail issues especially regarding with a type, an expectation, a dead line, a function and a leader role, a sigma structure, a secret, a group measurement, a membership, a duration in implementing peer groups process". By practicing a lot, learners can develop their English language competence easily as they hear and speak their words habitually (Lightbrown and Spada, 1999).

It was referred to a peer group, this action research was based on an initiative of a participant left who kept on having a high spirit since after they had learnt this EBL. The researcher found that their English mastery increased. The indicators of the participants were confident to communicate in English. Therefore, the researcher had a meeting on Sunday, september, 30 th 2018 with the head of RT 01 RW 02 kelurahan Cipedak
Jagakarsa Jakarta Selatan and Mushola Nur Thoha chairman located in Mushola.

In fact, it was approved by the head of RT 01 for EBL (English for A Better Life) were needed for the teenagers in the second levels; furthermore, an agreement among the the head of RT 01 Bapak Naim/the head of RW 02 Cipedak Bapak Amsari and Mushola community, Bpk Dedi Khairullah the second level of EBL was made to declare that the second EBL was continued. It was aimed to improve the teenagers' English skills so that it was expected that the participants who took part someday can get a better job. Consequentcy, the researcher and his team prepared the certificates for the participants. The other goal of this EBL was how the teenagers to get used to be positive attitude such as hospitality and so forth. Last but not least, the teenagers who joined were expected to worship (salat) to their God Allah SWT in Mushola Nur-Thoha since all of them were muslims.

The objectives of this study are (1) to improve the grammar understanding of the teenagers and (2) to enrich the teenagers' vocabulary of Karang Taruna of RT 001/RW 02 Cipedak Jagakarsa South Jakarta. Through applying this oral Questioning Guidance in L1 (OQIGIL) method, the English teachers always introspect themselves to improve their teaching quality from time to time based on the latest method especially the OQIGIL method so that their students are able to communicate in English after attending this EBL class. The learning method of Oral Questioning in L1 (OQIGIL) was developed by this researcher based on procedure systematically from one tried out to another one which fulfilled a standard, a quality, an accuracy and a certain efficiency. 


\section{METHOD}

In this case, serving the people to get a better life through action research was a special treatment, so that the classification of this EBL implementation was used an action research. It is clear that the main objective of action research is to apply for an English professional teaching which is toward to a good outcome for learners. Meanwhile, Mills in Creswell (2012:577) said that "Action research designs are systematic procedures done by teachers (or other individuals in an educational setting) to gather information about, and subsequently improve, the ways their particular educational setting operates, their teaching, and their students learning".

On the other hand, an action research design is a systematic procedure implemented by English teachers (or other teachers in education) to collect informations, to improve the operational of education implementation especially their teaching process, included learning students involving the role of their teachers. The objective of this action research in education, according to Ary (2010), was to create the attitude of investigation by questioning what the teachers have done in the classroom setting to fulfill their learners' needs. It is a must for English teachers especially since it is their main job included how to get used to teaching culture learning in their students' daily life.

The respondents of this action research were 13 teenagers of Karang Taruna members in Gang Resmi RT 001/RW 02 Cipedak South Jakarta. This action research was carried out from October to December 2018. The instrument used to collect the data was a postest and an interview in English or notes of anecdotal of observing during facilitating this action research. A piece of taking notes of anecdotal was an observing view report of observers as a collaborator of research team of this English action research.

The data obtained from the result of attitude observation of teenagers of RT 01/RW 02 Gang Resmi of EBL Program was taken by notes when this model was conducted by the reaserch chair since this OQIGIL method belongs to him and it has been registered in HKI No 028345 July 14, 2005. This action research was started in October to December 2018 taking more or less three months.

\section{RESULTS AND DISCUSSION}

The method used in this English for A better Life (EBL) was an Oral Questioning Guidance in Students' First Language (L1) (OQIGIL). In the first ten minutes, English grammar was explained by a special way such as a subject was like a mother. Mother consists of two. The new couple (a junior mother) which consists of "she, he, it". Adverb of frequency does not influence a predicate at all because it is regarded as a regular activity. Predicate consists of two. First it is called "father" second it is called "step father". The character of father is always moving to earn for his family. Example, the word "eat" if someone eats. He/she has to move especially his mouth and his teeth. If there is none or whatever after "mom" as a subject does not move, step father or is, am, are is placed there. Example: "I at home". Home does not move. So the step father which consists of (tobe: is, or am, are) is placed there which functions as a step father. The right sentence is: "I am at home". "Am" as a step father.

Furthermore, junior mother which has a special character "s" since "she" there is "s" so does "he, and it". 
Consequently, she, he, and it (a junior mother) are followed by "s" in the predicate or a father of the sentence. Example, she usually goes to school. "she" there is "s", "she is, there is "s". If it is followed by father, the father must be added by "s" it is like a ring for a new couple, Mom has a ring, dad must have a ring, too. Example. The dog is junior mom, run is a father. So, the father is added by " $\mathrm{s}$ ". The sentence is "the dog usually runs after the cat". It is only effective for a father who has a character "moving" to earn. Step father "is, am, are" is not added by "es/s." There is no rings for a step father. Next, there are two kinds of family. First. Transitive, A complete family, there is a mom, daddy, and children. Example. The child always eats breakfast. Second, intransitive, there is no any children. There are a mother and a father only. Example. The old man always gets up late.

Then, there are many kinds of servants. First, a servant who is paid by a father called "do" if a subject is a junior mother (she, he, it) "does" why does because, "es" belong to a father's ring to pay the servant. So father does not have "s" or es" anymore. The servant is used to make a question word like what, why, where, when. Example. Why do you usually come. Where does she live? Remember. "do" is paid by (1) a father. After question words must be followed by a servant. If it is negative (not). The servant "do" must come after a subject or a mom. Example. The girl does not come here today. Remember "not" is not a father, not a mother, not a child in the family. So, it is needed " a servant" to help. If there is no father. Father is replaced by a step father. A step father is tobe (is, am, are). Step father can be a servant. Example. She is not sick. (sick is not verb or father). Where is she, and so on.

A review is very important because it makes the learner aware of the sentence and its servant. Practice makes perfect. It is done by a researcher in this OQIGIL method. The participants were directed to speak English grammatically. If they forgot, the researcher reminded and helped them choose vocabulary and the grammar appropriately. Therefore, there were some steps to process the learners by OQIGIL method to communicate in English as follow:

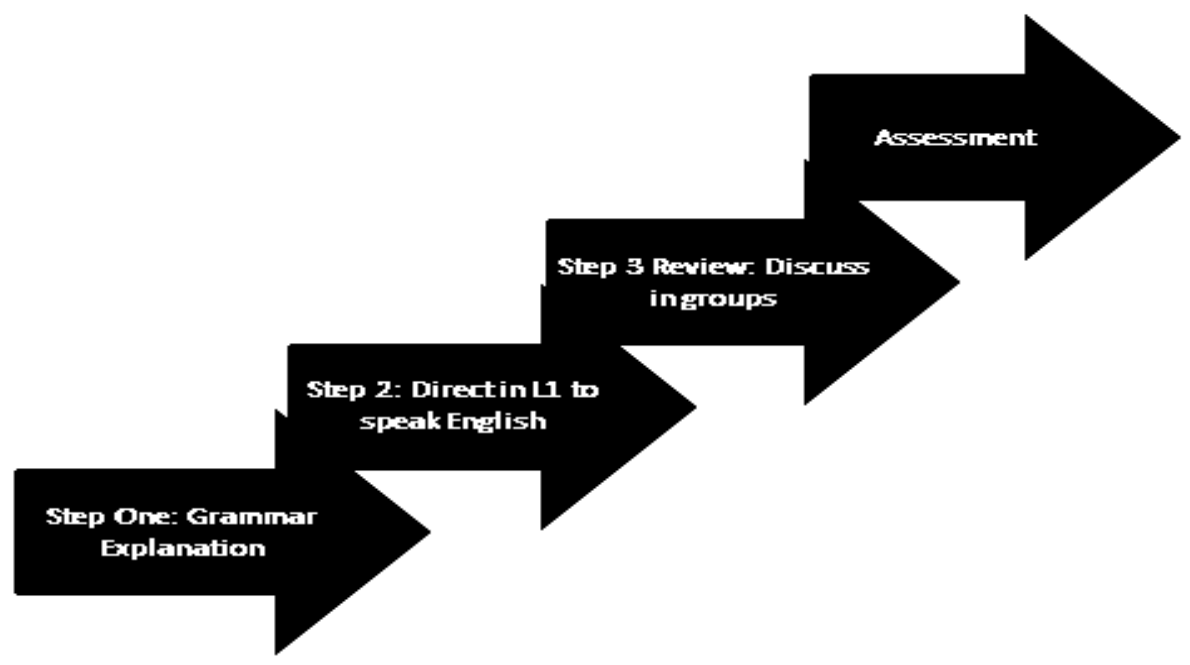

Figure 1

Steps in OQIGIL 
While the implementation of OQIGIL method in this EBL action research was below:

1. Opening and courtesy: the researcher introduced the standard of Muslim associaton and leadership. Next, looking at the attending list, and calling the participants' names one by one, and saying basmallah to start the opening.

2. The second session. The researcher explained the grammar during more or less ten minutes. Then he described how to make a right statement, ask and answer. Next, he directed the participants in L1 to speak English well. He reminded the grammar if they forgot and mentioned the right vocabulary if the students doubted. The researcher kept directing the participants by OQIGIL method to make them speak English appropriately. If the participants forgot, the researcher helped remind them. It took more or less 3 $\mathrm{x} 120$ minutes (first to the third sessions).

3. The Fourth sessions. It was a review of the second sessions. The researcher enriched the paticipants' vocabulary and improved their grammar understanding by implementing OQIGIL method included to ask and to answer grammatically in English.

4. The fifth sessions. The researcher examined the participants' competence dan performance to see how far they had understood grammar and how much vocabulary they had had. Then, the best, two or three students were appointed to be the leaders in peers groups to lead their peers to understand grammar and to enrich their vocabulary by using OQIGIL method with the textbooks in their hands. The researcher stood by to help the groups leaders direct their peers to understand grammar and to enrich the vocabulary. So, the researchers tried to form the new habit among of the paticipants to cooperate to do something. On the other hand, the participant not only got the competence and perfomance, but also the affection in their souls were grown by the researcher well. In the same time, the researcher assessed the learners' pronunciation, grammar and vocabulary used.

5. The sixth sessions. The researcher explained the next grammar (parts of speech) and also enriched the participants' vocabulary by using OQIGIL method. The participants were directed to speak English grammatically. If they forgot, the researcher reminded or helped them. It helped them speak English which consisted of two forms. First, they spoke English based on statements. Second, they asked and answered in English loudly. At last, some of them were confident to speak English grammatically. They talked based on some stories which contained "changing of verb included parts of speech adopted from the authentic ones especially taken from L.G Alexander Practice and Progress text book". It took around 20 minutes. Then, the researcher let them exchange their mind to each others.

6. The seventh sessions. The researcher evaluated the participant based on the materials given in the previous lessons. First, the researcher asked them in English. 
Second, the participants were asked to write a composition in English. Third, they were asked to perform to speak English after topic given in front of their peers. From there, they were accustomed to speaking English grammatically. At last, they were hoped to be confident to speak English well.

\section{CONCLUSION}

The findings of data analysis based on anecdotal notes are obtained a conclusion as follows: 1) The participants were active to study English since they enjoyed learning by this OQIGI method, 2) Three of the participants changed their learning style better; consequently, all of them got the third rank among thirty students in their class. In fact, they never got the third rank previously, 3) One of the learners always spoke English in his house since his father often asked him in English, 4) A university student, Miss Suci Nasution (Universitas Negeri Islam Jakarta semester 7 informed that she became an English private teacher to teach one of famous artists, 5) The last one who had been graduated senior high school got a job. It means that EBL (English for A Better Life) become true because the participants who joined in this EBL have got a better life.

\section{REFERENCES}

Ary, D. (2010). Introduction to Research in Education 8th. Canada: Nelson Education Ltd.

Blake, R. (2009). From web pages to distance learning: Technology in the foreign language curriculum. In Lancashire, I (Ed.), Teaching Literature and Language Online. 23-37.

Creswell, J. W. (2012). Educational Research: Planning, Conducting, and Evaluating Quantitative and Qualitative Research 4th. Boston: Pearson Education.

Lightbrown, P. M., \& Spada, N. (1999). How Languages Are Learned (Second Edition). Oxford: OUP.

Sangabakti, S. (2011). Strategi bimbingan kelompok untuk meningkatkan kemampuan siswa dalam mengelola stres di sekolah. Sosio e-Kons, 3(2).

Sriyono, H. (2011). Program bimbingan untuk membantu meningkatkan kemandirian belajar siswa. Sosio e-Kons, 3(2).

Supriyanto, E. (2006). Analisis Kebutuhan Tenaga Kependidikan Bagi Anak Cerdas Istimewa. Solo: Karya Pembina. 